\section{Ovarian failure after total body irradiation}

SIR, - Dr M P Cust and colleagues only touch on the possible long term effects of total body irradiation, ' but these need to be addressed as increasing numbers of patients are successfully treated.

We measured bone mineral content and density in the lumbar spine in 14 women who had premature ovarian failure after treatment for haematological malignancies. On average, 51 months had elapsed since treatment. We used a dual energy $x$ ray absorption technique with a precision of $1 \%{ }^{2}$ The patients' mean vertebral bone density was $0.97(\mathrm{SD} 0.15) \mathrm{g} / \mathrm{cm}^{2}$; that of a control group' of 68 women in the same age range ( 19 to 45 , mean age of both groups 33 years) was $1.07(0.09) \mathrm{g} / \mathrm{cm}^{2}$ $(\mathbf{p}=0.04$, Student's $t$ test). The patient with the lowest bone mineral density $\left(0.71 \mathrm{~g} / \mathrm{cm}^{2}\right)$ had already suffered an atraumatic fracture of a metatarsal bone.

The loss of almost $10 \%$ of bone mineral in this short time implies that these patients are at risk of developing osteoporosis in the future. We support the recommendation of Dr Cust and colleagues that they should be referred to a gynaecologist or endocrinologist to consider hormone replacement therapy.

MELANIE C DAVIES MARGARET L HALI H S JACOBS

Department of Medicine,

University College and Middlesex School of Medicine,

London WIN 8AA

1 Cust MP, Whitehead MI, Powles R, Hunter M, Milliken S. Consequences and treatment of ovarian failure after total body Consequences and treatment of ovarian failure after total body
irradiation for leukaemia. Br Med $\mathcal{J}$ 1989;299:1494-7. (16 irradiation
December.

Cullum ID, Ell PJ, Ryder JP. X-ray dual-photon absorptiometry: a new method for the measurement of bone density. Br. F Radiol 1989;62:587-92.

3 Hall ML, Heavens J, Cullum ID, Ell PJ. The range of bone density in normal British women. Br $\mathrm{J}$ Radiol (in press.

\section{Transvaginal colour flow imaging and ovarian cancer}

SIR,-In the discussion of their paper on transvaginal colour flow imaging Dr Thomas Bourne and colleagues state that to their knowledge no previous report on using colour Doppler imaging for differential diagnosis of ovarian masses has been published. ${ }^{\prime}$ Our report ${ }^{2}$ appeared several months before theirs, and we have presented data elsewhere. ${ }^{34}$

Since 1988 we have examined 5000 patients with a $5 \mathrm{MHz}$ transvaginal colour Doppler probe. We detected 147 ovarian tumours: 23 of these proved to be malignant. Diagnosis was confirmed by examination of diseased tissue (table). All of the malignant tumours showed prominent colour flow, and the calculated Pourcelot resistance index was $<0.40$ in all cases. By using this criterion we diagnosed two ovarian carcinomas of stage IA and one of stage IB. Only one false positive result

Blood flow in adnexal mass in 147 women with ovarian tumours according to pathohistological diagnosis

\begin{tabular}{|c|c|c|c|c|}
\hline \multirow[b]{2}{*}{ Pathohistological diagnosis } & \multirow[b]{2}{*}{ No of patients } & \multicolumn{2}{|c|}{ Colour flow } & \multirow{2}{*}{$\begin{array}{l}\text { Mean }(\mathrm{SD}) \\
\text { resistance index }\end{array}$} \\
\hline & & Present & Not present & \\
\hline Serous cystadenocarcinoma & 11 & 11 & & $0.34(0.09)$ \\
\hline Mucinous cystadenocarcinoma & 8 & 8 & & $0.35(0.06)$ \\
\hline Metastatic follicular cancer of the thyroid gland & 1 & 1 & & 0.25 \\
\hline Metastatic rectal cancer & $i$ & $i$ & & $0 \cdot 30$ \\
\hline Granulosa cell tumour & 2 & 2 & & $0.40(0.01)$ \\
\hline Dermoid cyst & 18 & & 18 & \\
\hline Simple ovarian cyst & 38 & & 38 & \\
\hline Hydrosalpinx & 13 & 1 & 12 & $0 \cdot 71$ \\
\hline Serous cystadenoma & 11 & & 11 & \\
\hline Mucinous cystadenoma & 9 & & 9 & \\
\hline Papillary cystadenoma & 2 & & 2 & \\
\hline Endometriosis & 32 & & 32 & \\
\hline Pseudocyst & 1 & 1 & & $0 \cdot 39$ \\
\hline
\end{tabular}

small, unilocular, thin walled and well demarcated adnexal cysts

\section{J L SEELEN} negative results. The sensitivity of this new diagnostic procedure was $100 \%$, specificity was $99 \cdot 2 \%$, and accuracy was $99 \cdot 3 \%$. The patients who had negative initial results were re-examined a year after the original procedure. No signs of pathological masses were found in this group.

ASIM KURJAK

IVICA ZALUD

Ultrasonic Institute, University of Zagreh,

41000 Zagreb, Yugoslavia

1 Bourne T, Campbell S, Steer C, Whitehead MI, Collins WP. Transvaginal colour flow imaging: a possible new screening technique for ovarian cancer. Br Med $\mathcal{J}$ 1989;299:1367-70. (2 December.

Kurjak A, Zalud I, Jurkovic D, Alfirevic Z. Transvaginal colou Doppler assessment of pelvic circulation. Acta Obstet (iynecol Scand 1989;68:131-5.

3 Kurjak A, Zalud I. Early diagnosis of ovarian tumours: transvaginal colour Doppler. In: Coppola V, Vallone GF, Verrengia D, eds. Stato dell'arte in ecografia. Vol 1. Naples: ATTI, 1989:189.

4 Kurjak A, Zalud I, Alfirevic Z, Jurkovic D. Transvaginal colour Doppler in the assessment of pelvic tumours. Ultrasound Med Biol (in press).

\section{Transabdominal ultrasound screening for early ovarian cancer}

SIR,-Professor Stuart Campbell and colleagues conclude that ultrasonography of enlarged adnexa in postmenopausal women has no value in differentiating benign from malignant lesions, and they consequently recommend surgical exploration in all patients with such lesions. This recommendation may have important implications for daily radiological practice. The increasing use of tota abdominal ultrasonography in patients referred to the radiology department ${ }^{2}$ yields many coincidental findings with potential clinical implications.

One such finding has been unilocular, thin walled adnexal cysts in postmenopausal women. Over two years we have found such cysts in 18 women without related symptoms. Diameters varied from $2 \mathrm{~cm}$ to $11 \mathrm{~cm}$ (mean $5.0 \mathrm{~cm}$ ). Sixteen of the women were operated on; all of the cysts were benign. Also, four postmenopausal women with asymptomatic thin walled, multilocular cysts were operated on, and no malignancy was found This experience is supported by other reports. With regard to the two malignant and three borderline malignant lesions that Professor Campbell and colleagues discovered, we would like to know their size, wall thickness, and demarcation from the surrounding tissue at operation and whether this correlated with the findings on ultrasonography.

Advocating surgical exploration of all enlarged adnexa in postmenopausal women, regardless of their ultrasonographic features will lead to considerable "overkill," and it seems reasonable to consider conservative management and follow up with ultrasonography in elderly patients with

\section{Westeinde Hospital,}

J B C M PUYLAERT

The Hague,

The Netherlands

1 Campbell S, Bhan V, Royston P, Whitehead MI, Collins WP. Transabdominal ultrasound screening for early ovarian cancer. Transabdominal ultrasound screening for

2 Mills P, Joseph AEA, Adam EJ. Total abdominal and pelvi ultrasound: incidental findings and a comparison between outpatient and general practice referrals in 1000 cases. $\mathrm{Br} \mathcal{J}$ Rudiol 1989;62:974-6.

3 Hall DA, McCarthy KA. The significance of the postmenopausal simple adnexal cyst. F C'trasound .Med 1986;5:503-5.

\section{Reduction of stress in carers of patients with dementia}

SIR, - I question one aspect of the methods of Dr $\mathrm{H}$ Brodaty and $\mathrm{Mr}$ Meredith Gresham described in their article. ${ }^{1}$ They mention that the exclusion criterion of greater than age 80 years was instigated for follow up purposes. I assume this to mean that they consider it more difficult to communicate with or track the very elderly than the young elderly. The mean age of patients studied was, not surprisingly, only $70 \cdot 2$. Unfortunately, because patients with dementia (and their spouses) tend to be quite a bit older I fear for the general applicability of this study.

Dr R Friedman and I have criticised research into diseases that affect mainly the elderly but is performed in subjects who are atypically young. Clearly, there are logistical problems in studying the aged. Nevertheless, for a condition such as dementia the practice of age restriction is most unfortunate and limits the effectiveness of an otherwise first rate study.

Sir Mortimer B Davis Jewish General Hospital

A M CLARFIELD

Montreal,

Quebec H37 1E2,

Canada

1 Brodaty $\mathrm{H}$, Gresham $M$. Effect of a training programme to reduce stress in carers of patients with dementia. Br Med f 1989;299. 1375-9. (2 December.)

2 Clarfield AM, Friedman R. A survey of the age structure of "age-relevant" articles in four medical journals. 7 . Am Geriatr Soc 1985;33:773-8

\section{Mortality among oral contraceptive users}

SIR, - Although generally we agree with Professor M P Vessey and colleagues' that the risks of using the contraceptive pill may have been overemphasised, we think that their comparisons with the mortality data of the Royal College of General Practitioners $^{2}$ are not entirely appropriate. Although the two cohort studies are almost contem porary, the royal college's analyses were based on data accumulated up to 10 years ago. This means that there is an important difference in the proportion of current users and former users who are combined as ever users in both reports. Thus in the royal college's report $54 \%$ of the total of 184000 person years of observation related to current use, while in the paper by Professor Vessey and colleagues only $34 \%$ of the total of 152000 person years represented current use.

This important difference would tend to produce smaller overall risk ratios between ever and never users as almost all of the excess mortality associated with use of the contraceptive pill is due to vascular disorders ${ }^{2}$ and is associated almost entirely with current use. ${ }^{3}$ It is noteworthy that the increased risk of myocardial infarction found by Slone $e t ~ a l^{+}$among women aged 40 to 49 years who had previously used oral contraceptives was not confirmed by them in a more recent case- 